\title{
Changing Paradigm of Consumer Experience Through Martech - A Case Study on Indian Online Retail Industry
}

\author{
Suresh Raghavan ${ }^{1}$, \& Ramesh Pai ${ }^{2}$ \\ ${ }^{1}$ Research Scholar, CMC, Srinivas University, Mangalore, Karnataka, India \\ Orcid ID: 0000-0002-4836-8344; E-mail: suresh@ sureshraghavan.in \\ ${ }^{2}$ Research Professor, CMC, Srinivas University, Mangalore, Karnataka, India \\ Orcid ID: 0000-0003-3019 -5745; E-mail: rameshpai080@ gmail.com
}

Area of the Paper: Business Management.

Type of the Paper: Research Case Study.

Type of Review: Peer Reviewed as per $|\mathrm{C}| \mathrm{O}|\mathrm{P}| \mathrm{E} \mid$ guidance.

Indexed In: OpenAIRE.

DOI: http://doi.org/10.5281/zenodo.5039649

Google Scholar Citation: $\underline{\text { IJCSBE}}$

\section{How to Cite this Paper:}

Raghavan, Suresh, \& Pai, Ramesh, (2021). Changing Paradigm of Consumer Experience Through Martech - A Case Study on Indian Online Retail Industry. International Journal of Case Studies in Business, IT, and Education (IJCSBE), 5(1), 186-199. DOI: http://doi.org/10.5281/zenodo.5039649.

International Journal of Case Studies in Business, IT and Education (IJCSBE)

A Refereed International Journal of Srinivas University, India.

Crossref DOI : https://doi.org/10.47992/IJCSBE.2581.6942.0109

(C) With Authors.

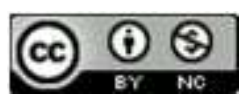

This work is licensed under a Creative Commons Attribution Non-Commercial 4.0 International License subject to proper citation to the publication source of the work.

Disclaimer: The scholarly papers as reviewed and published by the Srinivas Publications (S.P.), India are the views and opinions of their respective authors and are not the views or opinions of the S.P. The S.P. disclaims of any harm or loss caused due to the published content to any party. 


\title{
Changing Paradigm of Consumer Experience Through Martech - A Case Study on Indian Online Retail Industry
}

\author{
Suresh Raghavan ${ }^{1}, \&$ Ramesh Pai ${ }^{2}$ \\ ${ }^{1}$ Research Scholar, CMC, Srinivas University, Mangalore, Karnataka, India \\ Orcid ID: 0000-0002-4836-8344; E-mail: suresh@sureshraghavan.in \\ ${ }^{2}$ Research Professor, CMC, Srinivas University, Mangalore, Karnataka, India \\ Orcid ID: 0000-0003-3019-5745; E-mail: rameshpai080@ gmail.com
}

\begin{abstract}
Purpose: Retail selling is an inevitable economic activity in any country's economy. In India, the retail industry contributes $10 \%$ of its GDP. The invention of the Internet and technological advancement in digital marketing has helped the online retail industry to grow exponentially. Digital advancement has created an environment where customers are more informed, hence chooser and demanding. Marketing technology or 'Martech' encompasses technology to reach online customers to provide pre-eminent customer experience, to meaningfully engage and retain them. The latest such technologies are Artificial Intelligence, Augmented/Virtual Reality, Internet of Things, Natural Language Processing, Block Chain Technology, etc. This paper is an exploratory study using secondary data, which revealed that many firms have already adopted and most others are willing to adopt such advanced technologies in the near future as they are convinced that such technologies can phenomenally change the marketing strategies. This study also explores the current status of retail industry and also the opportunities and challenges of adopting these technologies from marketers' perspective. It also proposes suggestions from a user perspective, based on the analysis findings.

Design Methodology: Developing a conceptual framework using primary and secondary data collected from various studies published by the govt, global research firms, blogs, and other internet articles.
\end{abstract}

Findings: This paper revealed a dire need to adapt the marketing technology in the retailing industry for future survival. The analysis also revealed that the affinity for internet and online purchases is increasing exponentially hence the latest technology such as Artificial Intelligence, Internet of Things, Machine Learning, Augmented Reality/Virtual Reality, and Natural Language Processing are tremendously revolutionizing the customer experience and thereby increased level of Customer Engagement.

Type of Paper: Case study-based Research Analysis.

Keywords: Martech, Retail Industry, Customer Experience, digital marketing, Customer Engagement

\section{INTRODUCTION :}

The marketing world is undergoing a phenomenal transformation thanks to the development of digital technology. The last two decades have witnessed the development of several innovative technologies and applications in retail marketing as well as an enormous spending on both development and adoption of the same [1]. "Martech" a short form of Marketing technology, which implies the application of technology in marketing innovations. The prominent amongst such revolutionary technologies are Artificial Intelligence (AI), Internet of Things (IoT), Augmented Reality (AR) /Virtual Reality (VR), Natural Language Processing (NLP) and Block Chain Technology (BCT). Previous studies have shown that customer preferences, tastes and attitudes have also changed in line with the technological changes [2]. A customer survey showed that $40 \%$ of the respondents are willing to pay if the product is demonstrated through AR/VR and prompt them to visit more frequently if the retail shop is equipped with AR/VR [3]. Customers have shifted from traditional Brick and Mortar (B\&M) outlets to online platforms, namely e/m Commerce, due to convenience, ease of use, less time for shopping, availability of wider range of products, big savings, and the readily available comments from other users to 
understand the users' opinions about the products. In addition to this, the recent Covid 19 pandemic has witnessed enormous customer transference from offline to online to avoid physical proximity [4]. This instilled fear will only continue which will fuel further growth in online retailing. The retention of such informed customers by providing the best customer experience has posed a massive challenge to the marketers. Previous studies have shown that $5 \%$ of the fully engaged customers contribute up to $50 \%-80 \%$ of profitability than an unengaged customer [5]. Hence, customer retention and engagement has gained high prominence and drawn significant scholarly attention during the last decade. While technology is revolutionizing at a speed never before, providing the best customer experience has become more of a compulsion than choice. Martech thus has become a day-to-day word in marketing parlour.

\subsection{Evolution of online marketing in India:}

The retail industry in India stands second in the world, the value of which is projected to be US\$1.4Tn by 2024 [6] While online concept developed from the invention of internet in the early 1990s, postal marketing was available since 1877. The goods were used to be advertised in print media and customers used to buy by post. Payment used to be either sent before dispatch or paid to the post office at the time of receipt of the goods through Value Payable Post (VPP) [7]. Barring this, almost every retail good used to be bought from B \& M store. In India, Digital Online shopping concept started in 1995 with sift, Indiatimes, Yahoo, Rediff, etc. However, the online retail growth was sluggish due to the resistance from customers to change the traditional [8]. With the advancement in technology and the development of payment gateways, the purchasing convenience has increased, thereby leading to the exponential growth of retailing over last few years. This has transformed the online retail industry and at present there are hardly anything that cannot be purchased online!

\subsection{Martech:}

Martech is concerned with the usage of strategic technological solutions to achieve the marketing objectives [9]. Martech is perpetual and appropriate application technological innovations mainly digital marketing. The scope of marketing has been expanding [10] and the importance of Martech is growing steadily. The relevance of Martech is justified in view of the population of "Millennials" (Generation Y) who accounts for one-third of India's population. The main characteristics of this cohort are that they are highly informed about their rivals, impatient on their requirements, inflexible to preferences and highly demanding on customer service. They are also more vulnerable to their preference and taste changes, thanks to the plethora of options available online. Any firm that ignores this group will prove to be too costly to their business. While browsing through physical or online stores, they know the rival product [11][12]. The earlier survey shows that every customer in this segment has changed one product to another at least once, due to poor service. Martech intends to provide a memorable customer experience thereby enhancing the customer satisfaction.

\subsection{Emerging Technology for Marketing:}

With the initiation of newer technologies, many digital marketing tools tend to become obsolete in marketing. The data will play a critical role in marketing, whether in the selection of the product, product services, the prediction of customer preference, their engagement level and so on. The technologies that are revolutionising the marketing are enumerated briefly as follows:

\subsection{Artificial Intelligence (AI):}

Artificial intelligence, in contrast to the natural intelligence of human beings, are algorithms that read and process capable data of developing intelligence like human thinking or more, thereby arriving at logical inferences to make and execute decisions [13]. The application of AI in retail industry is boundless. It can be a chatbot, which can deliver information to the customer and execute approvals, loan in a bank or can replace a customer care executive in a call centre or to predict the customer preferences. Artificial intelligence helps the industry collect data, interpret meaningfully and thereby acquiring, retaining is possible in an easier way apart from enhancing the operational efficiency [14]. It can also replace the customer care executives and would be able to provide real time assistance to the customers round the clock. 


\subsection{Internet of Things (IoT):}

IoT involves connecting millions of physical objects to the Internet through computer chips, thereby making them a source of communication. It is estimated that about 5.8Billion units would be connected to internet by 2020 [15][16]. Retailers can benefit from this technology for enhancing customer experience, reducing cost, improving the operational performance and thereby enriching the customer satisfaction.

\subsection{Machine Learning (ML):}

Machine learning is a science in which computers are developed to learn the data and act, such as humans and to further learn automatically through observations and real-world interactions, with the help of specialised algorithms [17]. In the retail industry, one of the most important requirements is to predict customer demand. For example, ML along with AI and other automated machine learning tools is capable of predicting customer requirement at a place, on a particular day, even in a particular weather condition. Such capabilities will reduce the inventory-related costs significantly [18].

\subsection{Natural Language Processing (NLP):}

This is basically the manipulation of natural language such as speech and text and converts it into data for further communication. This eliminates the gap of communication between a human and a machine and helps in communication in a much efficient way, in the same way as a natural communication between two humans [19]. This capability of NLP can substitute human customer executives with bots thereby reducing the costs substantially [20].

\subsection{Block Chain Technology (BCT):}

Block Chain Technology or Distributed Ledger Technology (DLT) is the process of storing information in multi ledgers called "blocks" instead of a single one. It enhances the security of customer data and the operational performance [21]. This will also help increase the logistical efficiency, which ultimately increases customer loyalty and satisfaction among retail customers [22].

\subsection{Importance of improved customer experience:}

As online retailing has started revolutionizing, it has become imperative for the sellers to retain customers. This has Brought more attention to concepts such as Customer Experience (CX) and Customer Engagement (CE). A number of research is now happening as to how to provide the best customer experience on online retail industry.

\section{PREVIOUS STUDIES :}

Previous research shows that there is a significant association between the AR and user experience [23]. Similarly, other studies show that there is a positive association between the technology and the services in banking [24]. Another study reveals the customer intention to reuse the service if there is higher involvement of technology in the overall purchase process [25]. Further, Millennials have shown significant positive association in a technological retail platform [26], [27]. However, Susan Friorito in her studies indicated the darker side of the technology by which customers tend to change their brands more often as technological involvement is more in the purchases [28] This is because of their better awareness of the other products and hence vulnerable to changes in preferences and tastes.

\section{CONCEPTUAL FRAME WORK :}

A conceptual frame work has been formed as in the Fig. 1 showing the interrelations of various parameters that affect online retail purchases that leads to the customer satisfaction and the customer engagement [29][30]. 


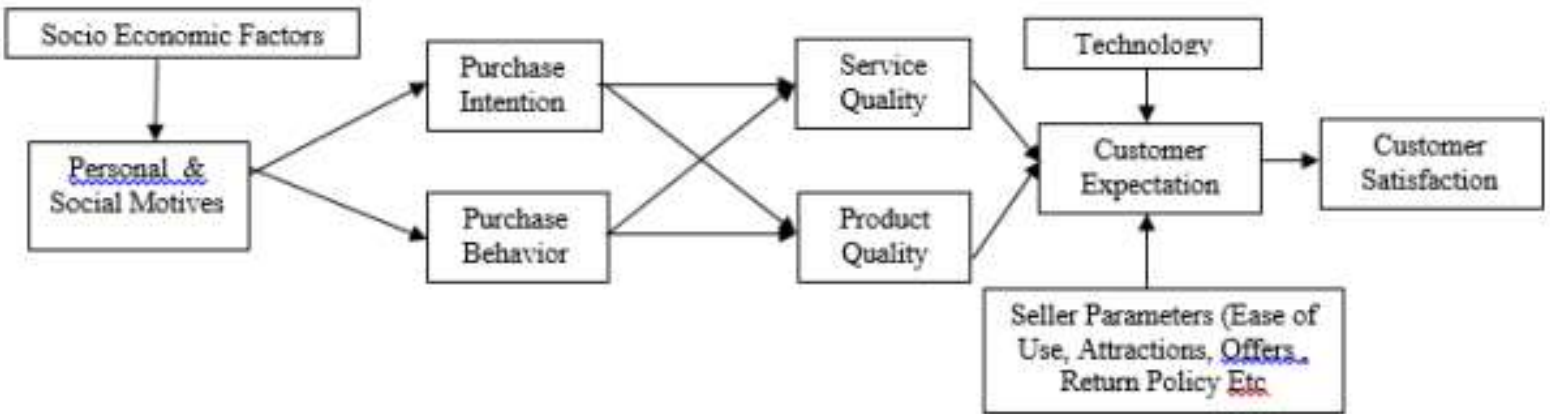

Fig. 1. Conceptual model of retail buyer seller engagement in advanced technology setting [29]

\section{STUDY OBJECTIVES :}

These paper intents to explore the following objectives:

(1) To explore the various technology dimensions that is transforming the online retail industry.

(2) To understand the growth pattern of the technology-driven customer experience that leads to customer satisfaction, being the very foundation of customer engagement.

(3) To critically analyse the Online retail industry using SWOC analysis.

(4) To propose suggestions based on the findings of the study.

\section{RESEARCH METHODOLOGY :}

The study is descriptive and exploratory in nature. The data collected include primary and secondary. Primary data were collected from the various reports published by Govt of India (IBEF) and other Govt Bodies. The secondary data were collected from published papers of reputed national and international marketing research firms, blogs, and scholarly publication journals.

\section{CASE ANALYSIS :}

\subsection{Growth of online retail:}

Until early 1990s, Indian retail industry has been thriving on brick and mortar stores as customers in India used to be very traditional and were very hesitant to buy the products without physically seeing it [31]. They were mostly confined to the stores near their residence where they were more comfortable with the people and their services. The customer experience and their engagement were more associated with the product and service quality provided by the store. The major disadvantage of such practices was attributed to the lack of awareness about the alternate brand as there was no other option of knowing about another brand. With the advent of internet, like any other developed and developing countries, Indian customers started buying online. Indian retail industry now is highly dynamic and poses for a huge growth. However, over the last two decades, Indian retail has been more dependent on the metro and tier 1 cities due to the lack of Internet penetration to tier 2 and tier 3 cities. In contrast, a last few years, online retail industry had witnessed a phenomenal increase in online purchases. According to Kearny's Global Retail Development Index (GRDI) [32], India now stands second amongst other countries in the world. Unfortunately, the pandemic Covid 19, may revise the figures of prediction since this has hit metros and tier 1 cities more seriously [33]. Brighter side of the pandemic is that, this has spurred the online purchase demand from tier 2 and tier 3 cities significantly to avoid physical proximity [34]. The current scenario of retail industry has been demonstrated graphically, from the survey reports of Indian Brand Equity Foundation (IBEF), a government body, conducted in 2019. Fig. 2 to Fig. 5 shows the survey reports of retail industry in India in 2019. 


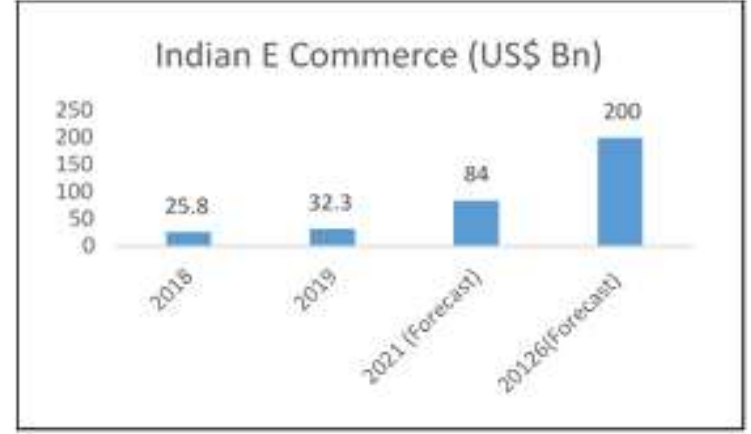

Fig. 2: Indian E Commerce Market Source : IBEF

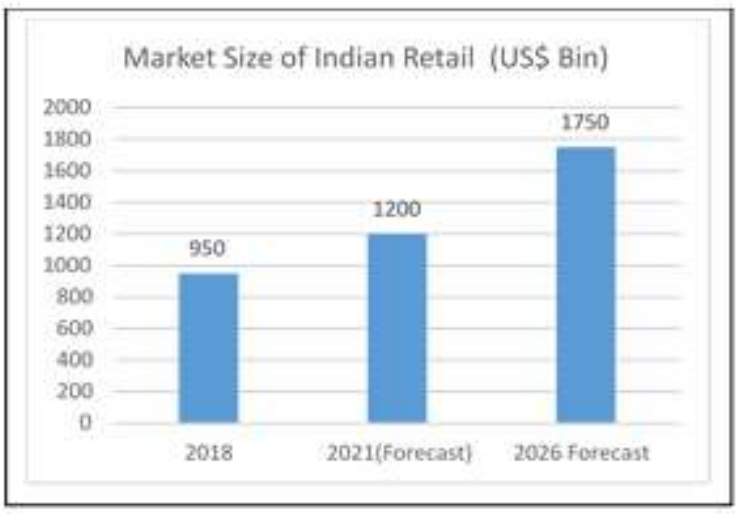

Fig. 4: Category wise break up of Total Retails Market

\section{Source : IBEF}

The findings of various surveys conducted on marketers in 2019-20, by international marketing research firms towards emerging marketing technologies are shown Table 1, Table 2, and Fig. 6 Fig.10.

Table 1: Intention of marketers to technology adaption

\begin{tabular}{|c|l|l|}
\hline $\begin{array}{c}\text { Sl. } \\
\text { No }\end{array}$ & \multicolumn{1}{|c|}{ Observed Parameters } & \multicolumn{1}{|c|}{ Interpretation } \\
\hline 1 & $\begin{array}{l}\text { 81\% of the respondents (Marketers) admit that } \\
\text { there would be increased investment in the } \\
\text { latest technology in next five years and only } \\
10 \% \text { expect the spend remains the same }\end{array}$ & $\begin{array}{l}\text { Most respondents are convinced about the } \\
\text { latest Martech and willing to invest in it }\end{array}$ \\
\hline 2 & $\begin{array}{l}41 \% \text { of the respondents are well aware of the } \\
\text { emerging marketing technologies, 38\% } \\
\text { somewhat aware and 21\% not aware at all }\end{array}$ & $\begin{array}{l}\text { A large percentage of marketers are yet to } \\
\text { understand/ be aware of the technologies. It is } \\
\text { predicted that as time passes, an increasing } \\
\text { number of marketers will be aware of such } \\
\text { technologies and benefits }\end{array}$ \\
\hline 3 & $\begin{array}{l}33 \% \text { intent to implement mantech within one } \\
\text { year, 41\% within 1-2 years and 26\% after 3 } 3 \\
\text { years }\end{array}$ & $\begin{array}{l}\text { Most of the marketers intent to invest within } \\
\text { 2years, which is a positive sign of growth in } \\
\text { adoption of latest technology. }\end{array}$ \\
\hline 4 & $\begin{array}{l}0 \% \text { respondents benefited out of mantech } \\
\text { within 1 year of implementation, 42\% within } \\
1-2 \text { yrs and 84\% after 3years }\end{array}$ & $\begin{array}{l}\text { The result period of such technologies is 2 - } \\
\text { 3yrs }\end{array}$ \\
\hline
\end{tabular}

Source : Martech 
International Journal of Case Studies in Business, IT, and Education (IJCSBE), ISSN: 2581-6942, Vol. 5, No. 1, June 2021

Table 2: Market perception of implementing such Martech

\begin{tabular}{|c|l|l|}
\hline $\begin{array}{c}\text { Sl. } \\
\text { No }\end{array}$ & \multicolumn{1}{|c|}{ Observed Parameters } & \multicolumn{1}{|c|}{ Interpretation } \\
\hline 1 & $\begin{array}{l}91 \% \text { of respondents believe that } \\
\text { Martech increases efficiency and return } \\
\text { on investment (ROI) }\end{array}$ & $\begin{array}{l}\text { High level of confidence in Latest technology that is a } \\
\text { positive indication of adoption of new technology }\end{array}$ \\
\hline 2 & $\begin{array}{l}62 \% \text { believe that it's a single platform } \\
\text { to track all digital activations }\end{array}$ & $\begin{array}{l}\text { Most respondents believe that it is more convenient to } \\
\text { track the customer digital activities }\end{array}$ \\
\hline 3 & $\begin{array}{l}60 \% \text { believe that they get better } \\
\text { insights from current marketing } \\
\text { activities }\end{array}$ & $\begin{array}{l}\text { The majority of respondents believe that new } \\
\text { technology will be beneficial for their future target } \\
\text { activities }\end{array}$ \\
\hline 4 & $\begin{array}{l}45 \% \text { believe they can save time and } \\
\text { other resources by automated activities }\end{array}$ & $\begin{array}{l}\text { Less than half of the percentage are convinced that it } \\
\text { will save time and other resources }\end{array}$ \\
\hline 5 & $\begin{array}{l}34 \% \text { believe that it will create better } \\
\text { sales attribution }\end{array}$ & $\begin{array}{l}\text { Most respondents are still not convinced that there } \\
\text { would be increased in sale due to the implementation of } \\
\text { advanced technology }\end{array}$ \\
\hline 6 & $\begin{array}{l}28 \% \text { believe that this will improve the } \\
\text { data security }\end{array}$ & $\begin{array}{l}\text { The majority of respondents are not convinced about } \\
\text { data security if the new technology is implemented. } \\
\text { Suitable measures shall be taken to improve this } \\
\text { apprehension }\end{array}$ \\
\hline
\end{tabular}

Source : Martech

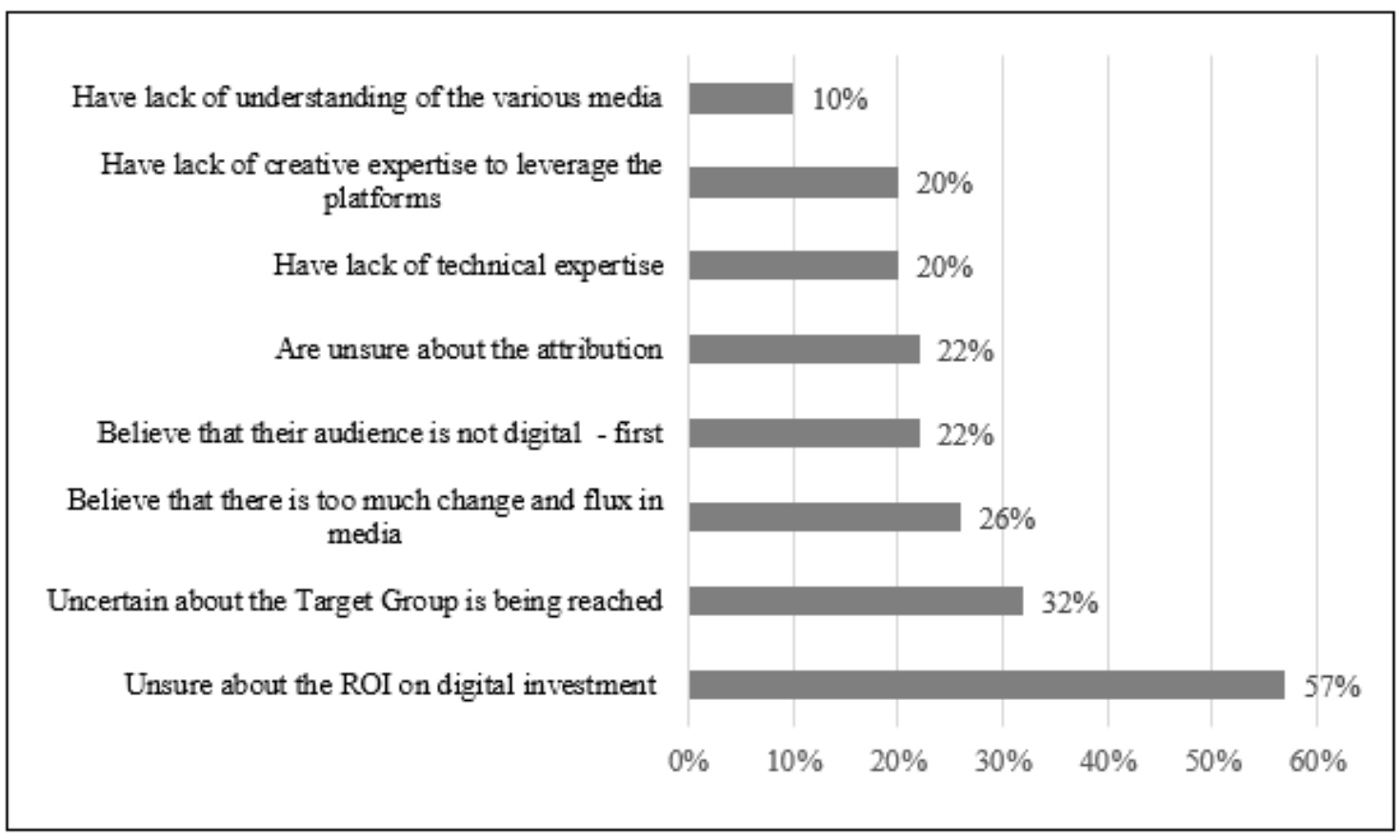

Source: Martech

Fig. 6: Challenges faced by the marketers using digital medium for marketing 


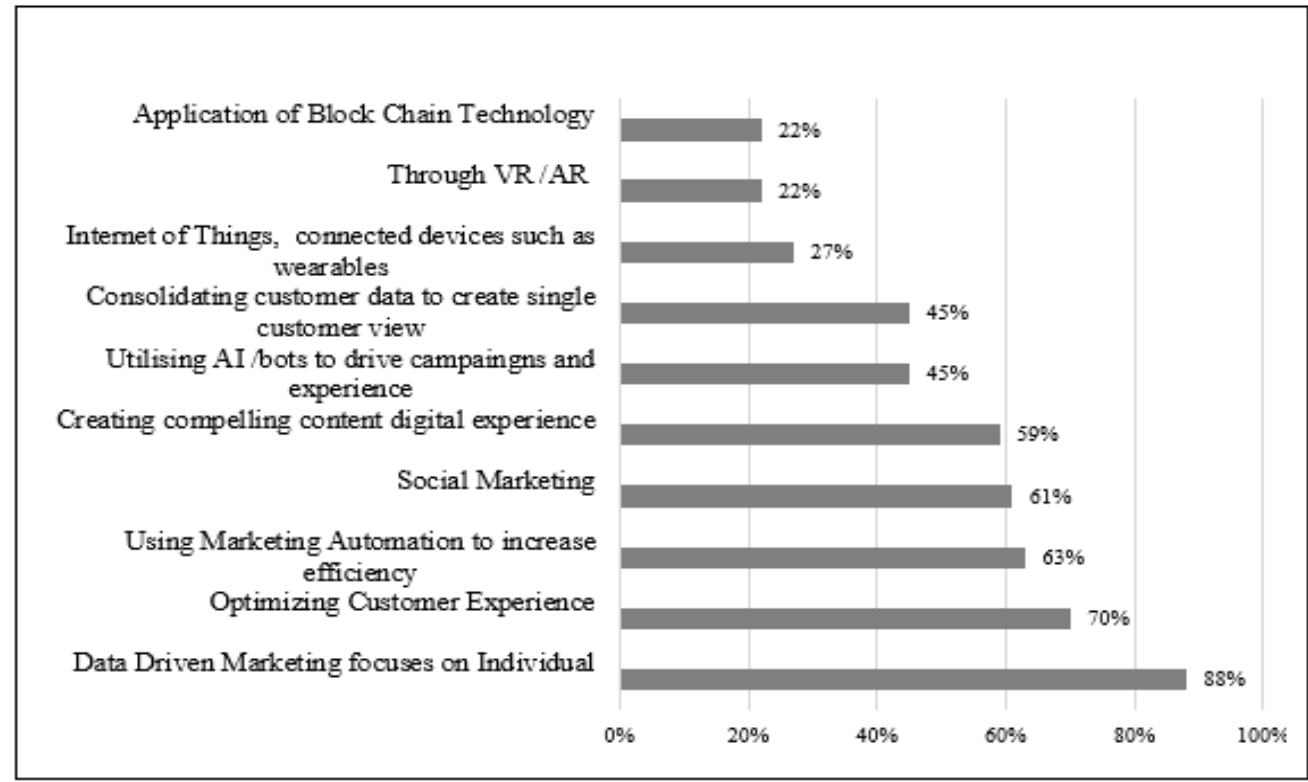

Fig. 7: Martech Tools that will create maximum Opportunity for the marketers in next two years Source: Martech

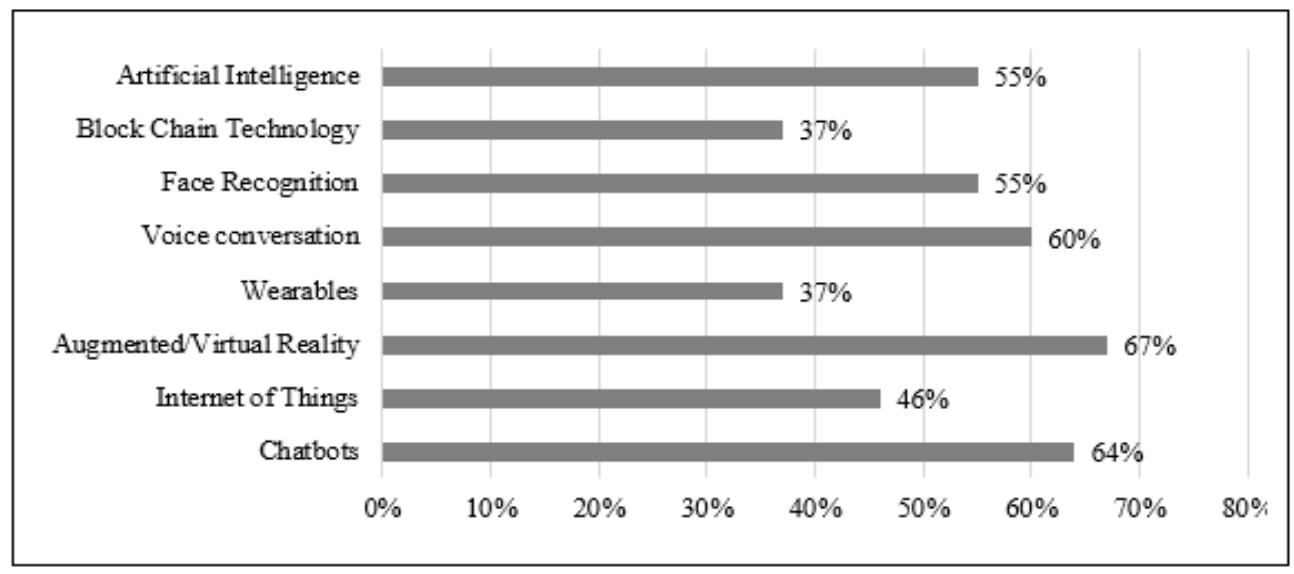

Fig. 8: Perceived Effectiveness by marketers upon adoption of emerging Martech Source: Martech

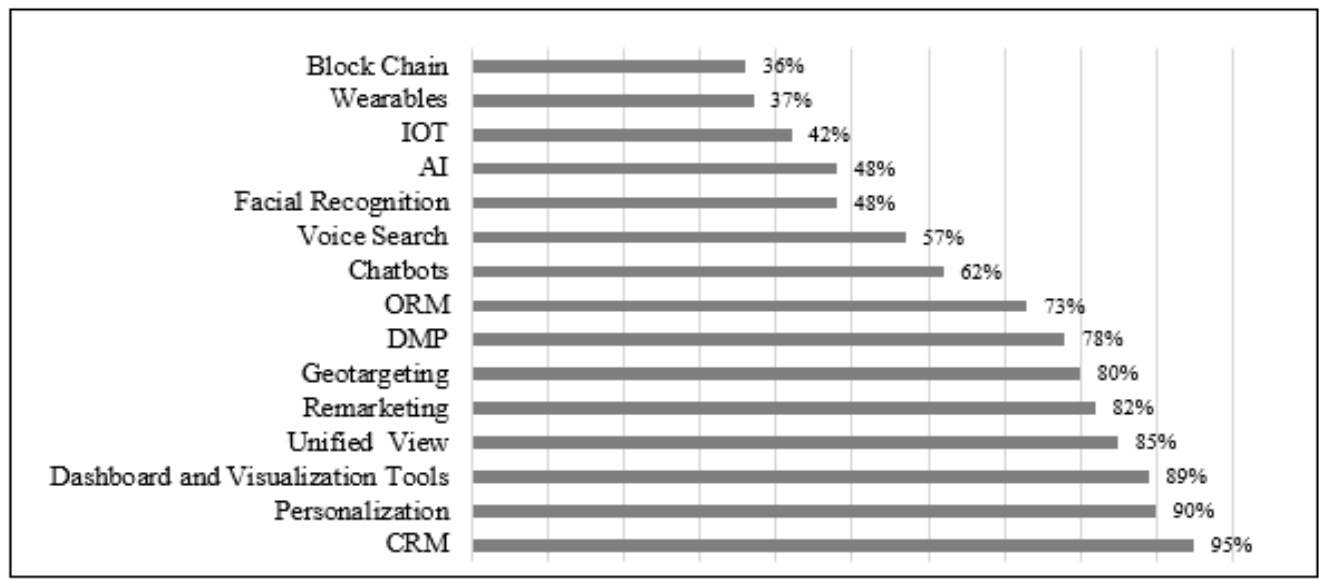

Fig. 9: Martech Tools that will make difference in customers' experience - Marketers' Perspective Source: Martech 


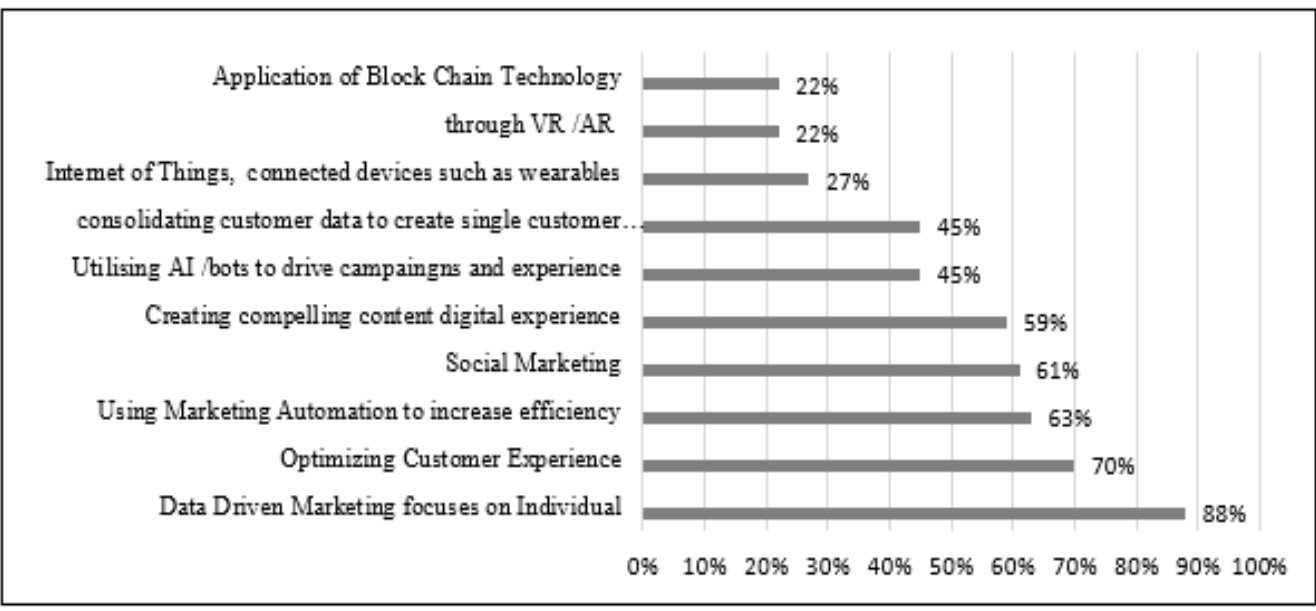

Fig 10. Martech Tools that will create maximum Opportunity for the marketers in next two years Source: Martech

\subsection{Growth Drivers:}

There are many favorable growth factors identified for fuelling the further growth of retail sales. Some of them are shown in Fig 11 below.

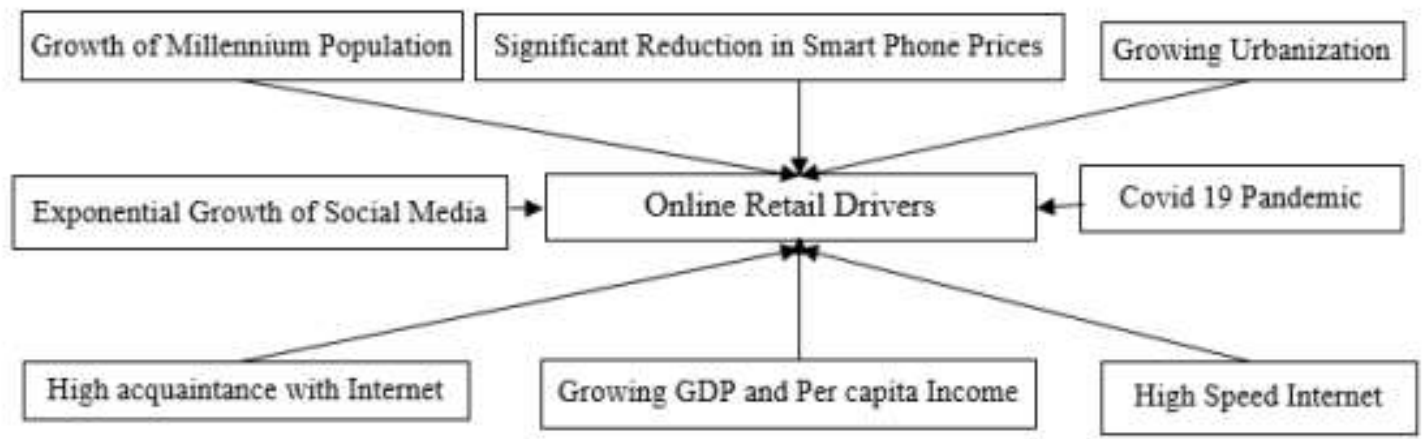

Fig. 11: Growth Factors of Online marketing

\subsection{SWOC Analysis:}

Based on the findings of various surveys and published reports, authors conducted a SWOC analysis to evaluate the current status of the online retail industry in India [35-38].

\subsubsection{Strength:}

- Indian retail industry is one of the fastest growing industries in the [39] and the fifth largest retail destination in the world. The major strength of the Indian retail industry is its population of $138 \mathrm{Cr}$ (as of 2020), which amounts to $17.5 \%$ of world population [40][41] Out of which 35\% are urban and $65 \%$ semi urban and rural population.

- Advancement of technology like AI, AR\&VR, IoT etc. are oriented to serve the common man in the years to come. This will certainly improve the relationship with the brands in online retail.

- The availability of 4G \& 5G internet to a large area including Tier $2 \& 3$ Cities. Thanks to India's growing infrastructure investments in laying optical fiber cable even in rural areas, high-speed internet is now available even in semi urban and some of the rural areas. This will strengthen the number of internet users and boost the retail industry.

- Less overheads and can offer better price. Second, no physical store hence no premises and running costs.

\subsubsection{Weakness:}


- Literacy is the key of online retailing. India's rural literacy is only $71 \%$ which mean more than one fourth of the population are yet to learn to read and write. This is an important road block to penetrate into the rural areas of the country.

- Low disposable income of an average Indian is too low compared to the developed world. Online retail growth largely depends on the disposable income of the citizen.

- Unemployment is one of the key indicators of any country's prosperity. India still has $5.36 \%$ unemployed population (Appx. 7.5Cr) that is not an ignorable number.

\subsubsection{Opportunities:}

- India has only $54.29 \%$ of Internet users, which indicates that almost half of the population are yet to be familiar with the internet and online retailing.

- As the infrastructure is developing in a faster mode, opportunity for this untapped lot will boost the sales

- The Millennials (Generation Y) which accounts for Apprx.34\% of the country's population is highly exposed to internet.

- Faster urbanization is a positive driving factor to the retail industries. Many rural areas are rapidly changing to their status to tier 1, tier 2. This is a very favorable factor for the retail sales, both online and offline. Changing Attitude of online retail customers due to Covid 19 Fear. At the onset of Covid 19 Pandemic, everyone was well aware of the fact that they need to maintain physical distance. This has changed the buying attitude of the customers who were otherwise depending on B\&M stores. This will trigger a huge growth in online retail. A large area of unpenetrated semi urban and rural India will open much bigger picture in online retailing.

\subsubsection{Challenges:}

\section{(1) Choosing the right Martech platform}

Indian retail industry is far behind the global retail industry in terms of technological sophistication. The above survey (Table 1) shows that there is a huge percentage of marketers who are yet to be aware of new technologies, its benefits and its cost - benefit implications. This lack of awareness will create only a slow pace of infusion of such technology in Indian retail online selling industry [42].

\section{(2) Inadequate funds to embrace the technology (Adopt and implement)}

Apart a lucky few, most of the domestic retailers are short of funds to invest in such futuristic technology which implies a huge acquisition cost. This will restrain them from adopting new technologies even if they have an intention to do so.

\section{(3) The unavailability of trained employees}

Market runs short of trained manpower for handling such digital platform. Dearth of such trained employees will be a huge challenge for retailers.

\section{(4) Company Attitude}

Many traditional companies are resistant to adopt new technology. They believe in the traditional way of marketing despite the massive change in retail buying attitude.

\section{(5) Low literacy of Rural Population}

Illiteracy and computer Illiteracy are predominant in rural India where $65 \%$ of the Indian population live. Though they are potential customers of tomorrow, due to less literacy rate, such technologies do not make any meaningful impact.

\section{(6) To address Cyber Security}

Cyber security has always been a road block to the developers. The above survey shows that even a majority percentage of marketers are not fully convinced that new technology could address the cyber security.

\section{(7) Providing best customer experience, retain them and engage them}

This is an extremely important parameter especially in an online retail market. The well informed customers are vulnerable to change. New technology shall be capable of addressing this issue providing an excellent customer experience thereby retaining such customers.

(8) International Competition

As the Indian retail sector is open to international players, the competency of Indian retail players 
shall be equally or close to the international players. Lack of product /service quality will strain the Indian players.

(9) Poor Supply chain Network

India has a poor supply chain network with respect to quality warehouses and poor transport facilities due to inferior supply chain infrastructure, compared to the developed country. This has affected the delayed/damaged delivery of products especially to the rural areas.

\section{SUGGESTIONS TO IMPROVE THE CUSTOMER EXPERIENCE, RETENTION AND ENGAGEMENT :}

In the light of various information compiled, following suggestions are put forward by the authors :

(1) Chat bots for Stores: One of the major disadvantages with online retail store is that, there is no one to ask about the quality and to question about the product, Brick and Mortar story. Many a times the customer has to assume or depend on customer reviews while buying the product. But most of the times this may not be the correct decision, and the same has to be returned to the supplier. This can be largely eliminated using a chatbot in the platform. Initially it may be implemented for certain categories for luxury goods, convenient goods and for products with a minimum product value. Such chat bots can solve this problem to a large extent.

(2) Hybrid Stores wherein online sales executives / Manufacturers are available on demand. This will fill the gap of physical presence of sales persons. This could also be Robots. Online retailing firms can introduce "Sales Person on demand" whereby, the platform can facilitate direct explanation of a sales executive about that product on video model. This will enable the customer to have a feel of physical shopping and avoid wrong choices. Ecommerce platforms can insist for the availability of sales persons whenever the customer demands for such services. The sales executive can chat through mobile or computer e commerce platforms. This may look difficult but it is possible since it is connected to each product in a decentralized way, this will improve the buyer seller relation as in a physical store and improve the satisfaction leading to higher loyalty.

(3) Robotic Video Selling: Retailers can connect to their physical store in a video mode and allow them to fit and trial through Augmented Reality / Virtual Reality: Robots can be utilized for video selling whereby the robot acts as a sales executive and clarify the doubts of the customer similar to a sales executive in a physical store. It can also assist to make the trials as in a physical store, through augmented Virtual reality. However, the return policy can still be maintained which will enhance the customer experience and satisfaction. This will avoid returning of the materials especially in the garment sector and will improve the sales dramatically.

(4) Availability of regional Languages: India is place where each state has separate languages and dialects. Natural Language process will enable the customers to converse in their own language and dialects. This will improve the communication in a much better way leading to more effective communication.

(5) Customization of Online products: There are many customers who want to customize their products. Robots can take the data and the required customers shall be enabled which will boost the sale of the product apart from being loyal to that brand.

(6) Robotic applications can be applied for resolving the complaints.

(7) Use of Artificial intelligence while choosing the product such as features of the products, USP, etc.

(8) Robotic Applications for Offers and cross selling.

(9) Transparent availability of Customer Life Value; Availability of data, touch points and offers related to target points that will prompt him to buy more.

(10) Robotic Cold Calls similar to personal selling which will enhance efficiency. Booking the appointment with customer, self-reminder, etc. are easily possible with robots than human beings.

(11) Facilitating interactive suggestions by the customers with humanoid robots. Natural Language Processing can facilitate the direct conversation with robots and suggestions can be recorded and passed on to the firm. 
(12) Robotic Reminder (Predictive) Selling or Proactive Selling. For example, Glucometer Strips were purchased for 30days, then give a call after 30days to the customer and induce interest.

(13) Instant crediting of payment for the returned items instead of waiting for days to return the money. This will enhance the customer experience and will be prompted to immediately go for alternate product.

(14) Online videos on demand for the real time videos of products, especially the food and beverage retailers.

(15) Design Ideas to make the customers participate online in the research and development process, in return for a reward.

(16) Facilitate real time online group meeting with the manufacturer to understand the group behaviour.

\section{CONCLUSION :}

As the technology advancement is at high level pace, application of various data based technologies such as AI, BCT, AR, VR, ML, NLP, etc. are revolutionizing the online retail market. Such applications now have already started delivering novel customer experience to the digital customers. The study findings show that there is tremendous potential with the application of these technologies to enhance the customer experience which leads to the better customer satisfaction and retention. The survey findings also show that majority of CEO /CMOs in India intend to invest in advanced technologies as their marketing strategy, to sustain their business growth in the world of digital customers. The trend indicates that those who do not embrace the new technology is bound to perish in the years to come.

\section{REFERENCES :}

[1] Grewal, D., Hulland, J., Kopalle, P. K., \& Karahanna, E. (2019). The future of technology and marketing: a multidisciplinary perspective. Journal of the Academy of Marketing Science, 48(1), $1-8$.

[2] Hopping, D. (2000). Technology in retail. Technology in Society, 22(1), 63-74.

[3] Retail perceptions (2016). The impact of Augment Reality in retail; Retail perceptions. http://www.retailperceptions.com/2016/10/the-impact-of-augmented-reality-on-retail/

[4] Alshaketheep, K. M. K. I., Salah, A. A., Alomari, et. al. (2020). Digital Marketing during COVID 19: Consumer's Perspective. WSEAS Transactions on Business and Economics, 17(1), 831-841.

[5] Renny Thomas et. al (2020). Reimagining customer engagement for the AI bank of the future, Mckinsey, https://www.mckinsey.com/industries/financial-services/our-insights/reimaginingcustomer-engagement-for-the-ai-bank-of-the-future.

[6] NASSACOM (2021). Indian Retail: AI Imperative to Data-Led Disruptive Growth Indian retail: AI imperative to data-led disruptive growth. https://nasscom.in/knowledgecenter/publications/indian-retail-ai-imperative-data-led-disruptive-growth.

[7] Sakshi education (2014). Introduction to the Postal System in India, sakshi education, https://www.sakshieducation.com/postal/Story.aspx?nid=72459.

[8] Baier, D., \& Stüber, E. (2010). Acceptance of recommendations to buy in online retailing. Journal of Retailing and Consumer Services, 17(3), 173-180.

[9] Baltes, L. P. (2017). Marketing technology (Martech): The most important dimension of online marketing. Bulletin of the Transilvania University of Brasov. Economic Sciences. Series V, 10(2), 43-48.

[10] Shah, D., \& Murthi, B. P. S. (2021). Marketing in a data-driven digital world: Implications for the role and scope of marketing. Journal of Business Research, 125(1), 772-779. 
[11] Soundarapandiyan, K., \& Ganesh, M. (2017). Understanding the perception of Millennial generation towards online shopping-A study with reference to Chennai. i-Manager's Journal on Management, 12(3), 31.

[12] Abhishek Malhotra \& Neelesh Hundekari (2016). How technology is redefining Indian Retail, https://retail.economictimes.indiatimes.com/news/industry/how-technology-is-redefining-indianretail/51106485.

[13] Weber, F. D. \& Schütte, R. (2019). State-of-the-art and adoption of artificial intelligence in retailing, Digital Policy, Regulation and Governance, 21(3), 264-279.

[14] Stamford, Conn (2020). Gartner identifies five emerging trends that will drive technology innovation for the next decade. https://www.gartner.com/en/newsroom/press-releases/2020-0818-gartner-identifies-five-emerging-trends-that-will-drive-technology-innovation-for-the-nextdecade

[15] Shyam Ravishankar (2020). Artificial Intelligence (AI) in retail 2021 - 7 Real world use cases ; vue blog, https://vue.ai/blog/intelligent-retail-automation/benefits-of-ai-in-retail-for-2021/

[16] Melanie Wachsman (2020). Zdnet, 5G won't impact many IoT projects anytime soon https://www.zdnet.com/article/survey-5g-wont-impact-many-iot-projects-anytime-soon/1

[17] Daniel Faggella (2020). What is machine learning? Znet, https://emerj.com/ai-glossaryterms/what-is-machine-learning/

[18] Andrii Kuranov (2020). Why does retail need machine learning? https://massmediagroup.pro/en/blog-mmg/5-examples-of-machine-learning-in-retail\#:

[19] Jason Brownlee (2019) What is Natural Language Processing? Machine Learning Mastery. https://machinelearningmastery.com/natural-language-processing/

[20] Maruthi techlabs (2021). What is NLP and 7 Reasons why everyone in retails should use it ? Maruthi techlabs. https://marutitech.com/what-nlp-reasons-everyone-retail-use- .

[21] Euromoney, (2020). What is block chain?, Euromoney. https://www.euromoney.com/learning/blockchain-explained/.

[22] Sharma.T (2020). Five ways block chain is transforming the retails industry, Block chain council. https://blockchain-ouncil.org/blockchain/five-ways-blockchain-is transforming-the-retailindustry/

[23] Poushneh, A., \& Vasquez-Parraga, A. Z. (2017). Discernible impact of augmented reality on retail customer's experience, satisfaction and willingness to buy. Journal of Retailing and Consumer Services, 34(1), 229-234.

[24] Ganguli, S. \& Roy, S.K. (2011). Generic technology-based service quality dimensions in banking: Impact on customer satisfaction and loyalty. International Journal of Bank Marketing, 29(2), 168189.

[25] Spreer, P., \& Kallweit, K. (2014). Augmented reality in retail: assessing the acceptance and potential for multimedia product presentation at the PoS. Transactions on Marketing Research, 1(1), 20-35.

[26] Soundarapandiyan, K., \& Ganesh, M. (2017). Understanding the perception of Millennial generation towards online shopping-A study with reference to Chennai. i-Manager's Journal on Management, 12(3), 31-40.

[27] Yeap Ai Leen, J., Thurasamy, R. \& Omar, A. (2012). Engaging Millennials in an evolving web environment: some key points for e-retailers. Business Strategy Series, 13(3), 111-117.

[28] Fiorito, S. S., Gable, M., \& Conseur, A. (2010). Technology: advancing retail buyer performance in the twenty-first century. International Journal of Retail \& Distribution Management, 38(11/12), 879-893. 
[29] Sashi, C. M. (2012). Customer engagement, buyer-seller relationships, and social media Management Decision, 50(2), 253- 272.

[30] Jana Lay-Hwa Bowden (2009). The Process of Customer Engagement: A Conceptual Framework. Journal of Marketing Theory and Practice, 17(1), 63-74.

[31] Sunil Patel, (2015). Evolution of online shopping in India \& its unparallel growth. International Journal for Research in Management and Pharmacy, 4(3), 24-33.

[32] Greg Portel (2019). A mix of new consumers and old traditions, Kearney, https://www.kearney.com/global-retail-development-index/2019.

[33] Siddharth Jain, Manoj Muthu Kumar \& Piyush Kumar (2020). India Retail Index: an analytical approach to enhance penetration and ride retail wave in India. Kearney. https://www.kearney.com/consumer-retail/article/?/a/kearney-india-retail-index.

[34] IBEF (2021). Retail survey Indian Retail Analysis, IBEF, https://www.ibef.org/uploads/industry/Infrographics/large/Retail-Infographic-February-2021.pdf

[35] Aithal, P. S., \& Kumar, P. M. (2015). Applying SWOC Analysis to an Institution of Higher Education. International Journal of Management, IT and Engineering, 5(7), 231-247.

[36] Aithal, P. S. (2017). An effective method of developing business case studies based on company analysis. International Journal of Engineering Research and Modern Education (IJERME), 2(1), 16-27.

[37] Aithal, P. S. (2017). Company Analysis-The Beginning Step for Scholarly Research. International Journal of Case Studies in Business, IT and Education (IJCSBE), 1(1), 1-18.

[38] Aithal, P. S. (2017). Industry Analysis-The First Step in Business Management Scholarly Research. International Journal of Case Studies in Business, IT and Education (IJCSBE), 1(1), 113.

[39] IBEF (2021, May 20). Indian Retail Analysis, IBEF, https://www.ibef.org/industry/indian-retailindustry-analysis- presentation\#

[40] Worldometer (2020). India population, https://www.worldometers.info/world-population/india $20 \mathrm{mi} 2$.

[41] Kromhout C. (2020, January 20). Life Insurance Opportunities for Millennials. Outlook money.https://www.outlookindia.com/outlookmoney/insurance/life-insurance-opportunities - for$\underline{\text { millennials-4206\# }}$

[42] Marketing evolution (2021). What is Marketing Technology and Martech? Marketing Evolution.https://www.marketingevolution.com/marketing-essentials/marketing technology-martech.

$* * * * * * * * * * *$ 